Summer 2009

\title{
Is There an International Environmental Constitution?
}

\author{
Daniel Bodansky \\ University of Georgia School of Law
}

Follow this and additional works at: https://www.repository.law.indiana.edu/ijgls

Part of the Constitutional Law Commons, Environmental Law Commons, and the International Law

\section{Commons}

\section{Recommended Citation}

Bodansky, Daniel (2009) "Is There an International Environmental Constitution?," Indiana Journal of Global Legal Studies: Vol. 16 : Iss. 2 , Article 8.

Available at: https://www.repository.law.indiana.edu/ijgls/vol16/iss2/8

This Symposium is brought to you for free and open access by the Law School Journals at Digital Repository @ Maurer Law. It has been accepted for inclusion in Indiana Journal of Global Legal Studies by an authorized editor of Digital Repository @ Maurer Law. For more information, please contact rvaughan@indiana.edu.

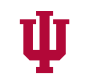

JEROME HALL LAW LIBRARY INDIANA UNIVERSITY Maurer School of Law
Blooming ton 


\title{
Is There an International Environmental Constitution?
}

\author{
Daniel Bodansky*
}

\begin{abstract}
The surge of interest among international lawyers in "constitutionalism" represents one of several efforts to reconceptualize international governance; others include the research projects on global administrative law and legalization. The article applies the constitutionalist lens to international environmental law-one of the few fields of international law to which constitutionalist modes of analysis have not yet been applied. Given the protean quality of the terms "constitution" and "constitutionalism," the article begins by unpacking these concepts. By disaggregating these concepts into a number of separate variables, which have more determinate, unambiguous meanings, we can answer the question, "Is there an international environmental constitution?", in a more nuanced way_not in an all or nothing fashion, but by considering the extent to which international environmental law has constitutional dimensions. The article concludes that, although individual treaty regimes have constitutional features, international environmental law as a whole lacks the hallmarks of a constitutional order.
\end{abstract}

\section{INTRODUCTION}

In recent years, there has been a surge in interest among international lawyers in "constitutionalism." Writers have variously argued that:

* Emily \& Ernst Woodruff Chair of International Law, University of Georgia School of Law. J.D. 1984, Yale Law School; M.Phil. 1981, Cambridge University; A.B. 1979, Harvard University. Many thanks to my student, Logan Pool, who helped me research and formulate the arguments in this article and to my research assistants, Kristin Roberts and Daniel Gelzer, who cite-checked this article. Thanks also to Dan Coenen, Harlan Cohen, Jeffrey Dunoff, Anne Herbert, Lori Ringhand, and the participants at the Kandersteg Workshop, who provided many useful comments and suggestions.

Indiana Journal of Global Legal Studies Vol. 16 \#2 (Summer 2009)

OIndiana University Maurer School of Law - Bloomington 
- An international constitutional order al ready exists, reflected, for example, in the U.N. Charter.'

- An international constitutional order is in the process of emerging. ${ }^{2}$

- An international constitutional order should emerge. ${ }^{3}$

These proposals to analyze international law in constitutional terms represent one of several efforts to reconceptualize international governance. Another is the research project on global administrative law, ${ }^{4}$ which, like constitutionalism, draws on domestic legal models to identify emerging patterns of international governance. Both reflect a broader emphasis on the phenomenon of legalization in international relations - the idea that international relations are increasingly governed by rules rather than merely power and interests. ${ }^{5}$

This article applies the lens of constitutionalism to international environmental law-one of the few areas of international law to which constitutional modes of analysis have not yet been applied. The subject of international environmental constitutionalism raises three principal questions:

- First, as a conceptual matter, what is constitutionalism? What would it mean to say that there is an international environmental constitution?

- Second, as a descriptive matter, to what extent is there an international environmental constitution? Or, to put it less categorically, to what extent does international environmental law have constitutional aspects or dimensions?

- Finally, as a normative matter, would it be desirable to have an interna-

1. See, e.g., Bardo Fassbender, The United Nations Charter as Constitution of the International Community, 36 Colum. J. Transwat'L L. 529 (1998); Christian Tomuschat, International Law as the Constitution of Mankind, in International Law on the Eve of the Twenty-first Century 37 (1997).

2. Erika de Wet, The International Constitutional Order, 55 INT'L \& CoMP. L.Q. 51 (2006).

3. Anne Peters, Compensatory Constitutionalism: The Function and Potential of Fundamental International Norms and Structures, 19 L.EIDEN J. INT'L L. 579, 582 (2006).

4. See, e.g., Benedict Kingsbury et al., Global Governance as Administration-National and Transnational Approaches to Global Administrative Law, 68 Law \& ConTemp. Probs. 1, 5 (2005) (discussing the early studies of the Global Administrative Law Research Project at New York University); Nico Krisch \& Benedict Kingsbury, Introduction: Global Governance and Global Administrative Law in the International Legal Order, 17 Eur. J. INT'L L. 1 (2006).

5. Judith Goldstein et al., Legalization and World Politics, 54 Int'L L. Org. 385 (2000) (presenting a special issue on legalization). Like constitutionalism and global administrative law, legalization has both a descriptive and a normative dimension. Descriptively, scholars have focused on actual processes of legalization, for example, greater reliance on hard sources of law such as treaties, more precise rules, and legalized methods of dispute resolution. Id. Normatively, some scholars have argued for strengthening the rule of law in international relations. See, e.g., Simon Chesterman, An International Rule of Law?, 56 A м. J. Coмp. L. 331 (2008); Jeremy Waldron, The Rule of International Law, 30 Harv. J. L. \& PUB. PoL'y 15 (2006). 
tional environmental constitution and, if so, why? In other words, what are the benefits of constitutionalism as a mode of governance in the area of international environmental law?

Although this article focuses primarily on the conceptual and descriptive questions, it also comments briefly on the normative issues. Given the Babel-like quality of the discourse about international constitutionalism, Part I begins by unpacking the terms "constitution" and "constitutionalism." By disaggregating these concepts into separate variables, which have more determinare, unambiguous meanings, we can answer in a more nuanced way whether there is an international environmental constitution. Part II concludes that although individual environmental treaty regimes have constitutional features, international environmental law as a whole lacks the hallmarks of a constitutional order. Should this be a source of concern? As Part III explores, there is no magic to the term "constitution," so debates about whether something amounts to a constitution can be a distraction. Nevertheless, the various dimensions of constitutional governance play an important legitimating role. By ordering and limiting government, constitutionalism helps justify an institution's authority to adopt rules, decide cases, and perform other governance functions. So an important question is, to what extent does international environmental law have constitutional elements? This question will become even more important in the future, as collective action problems, such as climate change, demand the exercise of greater authority by international institutions. To justify such authority, the legitimating power of more constitutional forms of governance could help to compensate for the declining role of state consent.

\section{What Do We Mean by Constitutionalism?}

\section{A. Three Initial Distinctions}

The terms constitution and constitutionalism are used in many different ways. When writers claim that international law has a constitutional character, for example, they may mean:

- International law has basic constitutive rules about how other rules are created, interpreted, changed, and enforced.

- International law contains fundamental substantive rules, such as the prohibition on the use of force and human rights protections. 
- International law constitutes a system, rather than merely a collection of discrete regimes.

- International law has a hierarchical structure; some norms are entrenched and superior to others in case of conflict.

- International law has a non-consensual dimension, reflecting more than simply a series of commitments by states.

- International law reflects process values regarding participation, transparency, and a separation of powers.

- International law is democratic.

Given the protean quality of the term, "constitution," when scholars disagree about whether some area of international law has a constitutional nature, it is often unclear whether the disagreements are real or whether they merely reflect differences about the term's meaning. In this regard, the current debates about constitutionalism are reminiscent of questions about "hard" versus "soft" law or about "law" versus "non-law," where it is also frequently difficult to determine whether people are arguing about substance or terminology.

In considering the discourse on international constitutionalism, it is useful to draw three initial distinctions.

First, we need to distinguish constitutionalism as a mode of political governance from constitutionalism as an intellectual movement. Constitutionalism as an intellectual movement within international law scholarship is interesting in its own right. ${ }^{6}$ What accounts for the increasing focus among international lawyers on constitutional governance? Does it reflect actual changes in international relations-an actual growth in constitutionalism as a mode of governance? Is it a reaction to increasing concerns about fragmentation and illegitimacy in international law-an attempt to put international law on a stronger normative footing? Can it be explained as an effort by European lawyers to extrapolate from the EU experience to global politics more generally? Does it serve an ideological function? Is it a power play by international lawyers by giving greater importance to judicial rather than political processes? Or is it simply academic talk-a way of giving a fashionable label to more prosaic features of international law? Although these questions are interesting, they are not the primary focus of this article, which instead addresses constitutionalism as a potential mode of environmental governance.

Second, we need to distinguish between the general concept of a constitution

6. See, e.g., Jeffrey L. Dunoff, Constitutional Conceits: The WTO's "Constitution" and the Discipline of International Law, 17 Eur. J. INT'L L. 647 (2006) (analyzing constitutionalism as an intellectual movement). 
and particular conceptions of constitutions. ${ }^{7}$ The general concept of a constitution, explored below, allows a variety of more specific conceptions, which define constitutions in fuller, more substantive ways. ${ }^{8}$ For example, Western liberal constitutionalism emphasizes such important features as democracy, separation of powers, checks and balances (including, in particular, judicial review), and protections of fundamental civil and political rights. This more particular conception of a constitution has many virtues, but its features are not intrinsic to the general concept of a constitution.

Finally, we need to distinguish between a constitution, on the one hand, and constitutionalism more generally. A constitution consists of the fundamental rules governing a political community and is generally, but not always, in written form. In contrast, constitutionalism refers to the broader set of qualities or values associated with the liberal conception of a constitution, ${ }^{9}$ such as limited government and the dignity of the individual. These values and qualities collectively reflect what Martti Koskenniemi has referred to as a "constitutional mindset." ${ }^{10}$ Because constitutions and constitutionalism are distinct, it is possible to have either constitutions without constitutionalism (as was true in former communist countries and in some developing countries), or constitutionalism without a constitution. ${ }^{11}$

\section{B. The Concept of a Constitution}

How should we understand the concept of a constitution? At the most general level, a constitution is a higher body of law, typically of an enduring nature, setting forth the fundamental rules of a political community. ${ }^{12}$ These rules can be

7. Both Ronald Dworkin and John Rawls make use of this distinction between "concepts" and “conceptions." See Ronald Dworkin, Law's Empire 70-71 (1986); John Rawls, A Theory of Justice 5 ( 1971).

8. Dunoff masterfully surveys the range of conceptions of constitutionalism put forth by international trade lawyers. See Dunoff, supra note 6, at 657; see also Joel P. Trachtman, The Constitutions of the WTO, 17 Eur. J. INT'L L. 623 (2006) (identifying the many dimensions of constitutions as economic, interfunctional, political, legal and judicial, human rights, and redistributive).

9. Peters, supra note 3 , at 581.

10. Martti Koskenniemi, Constitutionalism as Mindset: Reflections on Kantian Themes About International Law and Globalization, 8 ThEORETICAL INQUIRIEs L. 9, 18-19 (2007).

11. See generally Vicki C. Jackson \& Mark Tushnet, Comparative Constitutional Law (1st ed. 1999) (including chapters entitled "Constitutions Without Constitutionalism" and "Constitutionalism Without a Constitution?").

12. See generally K.C. Wheare, Modern Constirutions (2d ed. 1966); cf. Peters, supra note 3, at 581 (defining a constitution as "the sum of basic (materially most important) legal norms which comprehensively regulate the social and political life of a polity"). Because a constitution consists of the 
of two types. First, constitutions set forth the procedural rules that establish the basic political institutions of a community and define how other norms are created, interpreted, changed, and enforced-what H.L.A. Hart called "secondary rules" and Bardo Fassbender refers to as "metarules."13 Second, constitutions may also contain substantive rules, such as basic human rights protections. Although these substantive rules are not as obviously constitutive as the procedural rules that establish the basic framework of government, they also help create a political community by defining its core values.

Thomas Gray notes that constitutions can vary along many dimensions. ${ }^{14}$ They can be enacted (as in the case of the U.S. Constitution) or arise through a customary process (as in the case of the British Constitution). ${ }^{15}$ They can have an extra-legal status or the status of ordinary or fundamental law. They can be enforced through political or judicial processes. They can be federal, unitary, or confederate. Also, they can be defined narrowly to include just the formal rules in a particular document or more broadly to include all of the fundamental rules of a political community, formal and informal, written and unwritten. ${ }^{16}$

Notwithstanding these variations, constitutions typically share the following features.

"rules" of a political community, it does not simply consist of a description of how a community is governed, but necessarily contains a normative aspect. See Thomas Cottier \& Maya Hertig, The Prospects of 21st Century Constitutionalism, 7 Max Planck Y.B.U.N.L. 261, 279 (2003) (distinguishing "descriptive" and "normative" concepts of a constitution). It should be noted that Cottier and Hertig's distinction between "descriptive" and "normative" differs from this article's usage; for them, the term "normative" refers simply to the rule-like character of constitutions.

13. H.L.A. Hart, The Concept of Law 77 (1961); Bardo Fassbender, The Meaning of International Constitutional Law, in Towards World Constitutionalism: Issues In The Legal Ordering of THE World Community 837, 842 (Ronald St. John MacDonald \& Douglas M. Johnston eds., 2005). Alfred Verdross sees an international constitution as establishing "those norms which deal with the structure and subdivision of, and the distribution of spheres of jurisdiction in a community." Id.

14. Thomas C. Grey, Constitutionalism: An Analytic Framework, in Constitutionalism 189, 192-93 (J. Roland Pennock \& John W. Chapman eds., 1979).

15. Of course, this dichotomy is an oversimplification, since in most cases constitutions involve a combination of enacted and customary norms. For example, although the U.S. Constitution is primarily enacted, some of its norms have had a customary character (the two-term limit on the presidency, for example, arose through a customary process before ultimately being enacted through the Twenty-Second Amendment). Conversely, while much of the British constitution arose through a customary process, Her Majesty's Stationery Office, as of 1995, listed thirty-eight Acts of Parliament in its volumes on "constitutional law," including the Articles of Union with Scotland and Northern Ireland. See S.E. Finer et al., Comparing Constitutions 40 (1995).

16. WheAre, supra note 12 , at 14 (distinguishing broad and narrow meanings of a "constitution"). 
First, they aim primarily to regulate governmental rather than private actors; they represent a type of public law rather than private law. Most attempts to adopt constitutional limits on private conduct have floundered, such as the Twenty-First Amendment in the United States, which prohibited the sale of alcoholic beverages. ${ }^{17}$

Second, because constitutions address fundamental issues and are intended to provide a stable framework of governance of indefinite duration, they typically are entrenched, meaning that they are more difficult to change than ordinary laws. In some cases entrenchment is formalized by requiring special procedures for amendment, such as supermajority voting. In other cases the entrenchment is informal, as is true of the British constitution. In this context, entrenchment results from a social norm rather than a legal requirement. In either case, entrenchment serves to take constitutional issues outside the zone of normal politics.

Third, constitutions typically take precedence in cases of conflict with other norms. Constitutions represent a hierarchically superior form of law, which trumps ordinary legislation. ${ }^{18}$ Analytically, superiority and entrenchment are distinct. A norm could be superior but not entrenched or entrenched but not superior. Generally, however, constitutions share both features, because both entrenchment and superiority derive from the same source: the fundamental nature of the rules contained in a constitution.

Of course, these three features are not shared by all constitutions. They are not necessary conditions of a constitution, even in a thin sense. Most constitutions have a special legal status, but some have the status of ordinary statutes. Indeed, in some respects, the British constitution does not even have a legal character, let alone a supra-legal character. Instead, the concept of a constitution is better seen as a family resemblance, ${ }^{19}$ reflecting various features that are generally shared by systems of governance that we characterize as constitutional.

For this reason it seems misguided to attempt to define the necessary and sufficient conditions of a constitution, and then to measure systems of governance that aspire to this status based on these defining features. Instead, we need to employ a less categorical approach in considering whether an international environmental constitution has emerged. As will be demonstrated below, the constitutional character of governance is not a matter of yes or no, but of more or less.

17. The Thirteenth Amendment to the U.S. Constitution, outlawing slavery, is a notable exception. U.S. Const. amend. XIII, $\S 1$.

18. In Roman law, the "constituo" was "imperial legislation that transcended all other law." Douglas M. Johnston, World Constitutionalism in the Theory of International Law, in Towards WorLd ConSTITUTIONALISM, supra note 13 , at 3, 17.

19. Grey, supra note 14 , at 191. 


\section{What Functions Do Constitutions Serve?}

Constitutions are sometimes depicted as limitations on public power. ${ }^{20}$ Yet they, in fact, serve dual functions, both constituting and constraining power. ${ }^{21} \mathrm{As}$ the term constitution suggests, constitutive rules that define the basic values, institutions, and decision-making processes of a political community are central to the concept of a constitution. ${ }^{22}$

Of course, in modern liberal constitutions, substantive limits, such as guaranteed human rights protections, are also common. But it is worth remembering that, in the case of the United States, the Bill of Rights was not part of the original constitution. In its original form, the U.S. Constitution was almost entirely constitutive, ${ }^{23}$ defining the basic structure of government, including the separation of powers among the three branches of the federal government and the relationship of the federal government to the states. It was adopted not so much to limit public power-the federal government under the Articles of Confederation had few powers to begin with-but rather to create a new government with stronger powers. This is true of most constitutions; they are conceived as creative, even revolutionary instruments, either establishing a new political order or providing a fresh start for an existing one.

Nevertheless, the widespread emphasis on the constraining nature of constitutions is well-founded, since a central feature of constitutional governance is its limiting character. This feature is most obvious in the case of constitutions that impose substantive constraints on power. Examples include prohibiting ex post facto laws and protecting human rights. But even when a constitution is purely constitutive, it is still constraining. The procedural rules set forth in a constitution do not simply create institutions. They also define and thereby limit those institutions, similar to the way that the rules of a game both create the game and limit the moves that a player can make.

By limiting governmental authority, constitutions serve an important legitimating function. A constitution creates, as John Adams put it, "a government of

20. For a classic articulation of the view that constitutions serve as limitations on government, see Giovanni Sartori, Constitutionalism: A Preliminary Discussion, 56 Aм. Pol. Sci. Rev. 853 (1962).

21. See Graham Maddox, A Note on the Meaning of "Constitution", 76 AM. Pol. Scl. Rev. 805, 805 (1982) (challenging Sartori's view and arguing instead that constitutions are a "combination of... power and its control").

22. The Latin term "constituere" means to set up, establish, or construct. See id. at 807.

23. The Contracts Clause is one of the comparatively few substantive rights provided for in the U.S. Constitution itself. U.S. Const. art. $1, \S 10$. 
laws, not of men" ${ }^{24}$ - or in the case of international law, not of states. ${ }^{25}$ In this respect, constitutionalism is closely related to legalization. ${ }^{26}$ But constitutionalism goes beyond legalization by limiting the legislature through a body of rules that are fundamental, entrenched, and hierarchically superior to ordinary law. ${ }^{2 i}$ Such constitutional limits make governance less democratic and flexible, but also provide compensating benefits-most importantly, stability, predictability, and security against the threat of unrestricted government power.

That said, the limits imposed by constitutions are often pliable in ways that ordinary laws are not. Because they establish ongoing systems of governance intended to persist indefinitely into the future and difficult to amend, constitutions must be framed with a certain level of generality. They must allow considerable flexibility if they are to avoid becoming outdated. This open-ended quality of constitutions is manifested both in the doctrine of implied powers, which is stated explicitly in the "necessary and proper clause" of the U.S. Constitution and has been inferred in the case of international organizations, as well as in the more spacious approach often employed to interpret constitutions as compared to ordinary laws. ${ }^{28}$

24. MAss. Const. art. XXX (1780), available at http://www.nhinet.org/ccs/docs/ma-1780.htm (identical language still exists in the current Massachusetts Constitution). The phrase was originally used by John Adams in 1774. John Adams, Novanglus Essay, No. 7, available at hitp://en .wikisource.org/wiki/Novanglus_Essays/No._7.

25. Peters, supra note 3 , at 583.

26. The relationship between constitutionalism and legalization is even closer to the extent that the rule of law is conceived as having substantive as well as procedural aspects.

27. See Philip Allott, Intergovernmental Societies and the Idea of Constitutionalism, in THE LEgitimacy of International Organizations 69, 90 (Jean-Marc Coicaud \& Veijo Heiskanen eds., 2001) (characterizing constitutionalism as "more than a rule of law and less than natural law"). Particular conceptions of constitutions may contain additional legitimating features, such as separation of powers and human rights protections.

28. Cf. John Marshall's famous phrase in McCulloch v. Maryland, 17 U.S. 316 (1819) ("We must never forget that it is a Constitution we are expounding"); see also Benjamin Cardozo, The Nature of the Judicial Process 83 (1921) ("A constitution states or ought to state not rules for the passing hour, but principles for an expanding future") (emphasis in original). It should be noted that many leading constitutional scholars, particularly in the United States, reject the view that constitutions should be interpreted in a more teleological manner than ordinary statutes and instead advocate an originalist or strictly textualist approach. As Jan Klabbers notes, the tension between a constitution's constraining function and its open-ended, "living" nature is nicely captured in Wheare's observation that courts "may choose to treat a constitution as a living instrument, but they must treat it first of all like a constitution." Jan Klabbers, Constitutionalism Lite, I Int'L Org. L. Rev. 31, 52 n.101 (2004) (quoting K.C. Wheare, Federal Government 237 (1947)). 


\section{Is THERE AN INTERNATIONAL ENVIRONMENTAL CONSTITUTION?}

As the preceding discussion makes plain, claims about international constitutionalism can mean several things. At the lowest level, they call attention to the constitutive aspects of many international agreements. ${ }^{29}$ Numerous international environmental agreements have a constitutional dimension in this thin sense. ${ }^{30}$ Rather than elaborate a set of static commitments by states, they are dynamic arrangements that establish ongoing systems of governance to address particular issues like climate change, ozone depletion, or whaling. Although they differ in their particulars, each international environmental agreement performs basic constitutive functions by establishing institutions, specifying the rules that guide and constrain these institutions, and entrenching these rules through amendment procedures.

Consider, for example, the 1946 International Convention for the Regulation of Whaling (ICRW) ${ }^{31}$ In contrast to earlier whaling agreements, which had consisted solely of specific regulatory limits on whaling, ${ }^{32}$ the ICRW served a constitutive function as well. It established the International Whaling Commission (IWC) and authorized it to adopt regulations on an ongoing basis by a threequarters majority vote. ${ }^{33}$ The particular regulatory limits imposed by the ICRW are now long forgotten. But the ongoing system of governance it established has proven remarkably robust, eventually leading to the adoption of a moratorium on commercial whaling, which continues to this day.

Many other environmental treaties similarly serve a constitutive as well as a regulatory function. For example, the 1987 Montreal Protocol on Substances that Deplete the Ozone Layer (Montreal Protocol) ${ }^{34}$ not only set forth targets and timetables to reduce the use of certain ozone-depleting substances, but also established procedures to amend and adjust these regulatory requirements. This has led to a progressive tightening of the reduction schedule for chlorofluorocarbons and halons, the two classes of chemicals originally addressed, as well as the inclu-

29. Peters refers to this as "micro-constitutionalist" analysis. Peters, supra note 3 , at 594.

30. Cf. Joseph Raz, On the Authority and Interpretations of Constitutions: Some Preliminaries, in Constitutionalism: Philosophical Foundations 152, 153 (Larry Alexander ed., 2001) (distinguishing "thin" and "thick" senses of a constitution).

31. International Convention for the Regulation of Whaling, Dec. 2, 1946, 62 Stat. 1716, 161 U.N.T.S. 72 [hereinafter ICRW].

32. For example, the 1931 Whaling Convention prohibited the taking of right whales as well as immature whales and female whales accompanied by calves or suckling whales. International Convention for the Regulation of Whaling, Sept. 24, 1931, arts. 4, 5, 115 L.N.T.S. 349.

33. ICRW, supra note 31 , arts. III, V.

34. Montreal Protocol on Substances that Deplete the Ozone Layer, Sept. 16, 1987, 1522 U.N.T.S. 3. 
sion of numerous other ozone-depleting substances in the Montreal Protocol's regulatory scheme, including carbon tetrachloride, methyl chloroform, and hydrochlorofluorocarbons. ${ }^{35}$

As constitutive instruments, treaties like the ICRW and the Montreal Protocol typically represent the tip of the normative iceberg within the regimes they establish. The majority of the norms are created not by the original treaty itself, but by the more flexible and dynamic governance arrangements constitured by the treaty. International environmental regimes usually distinguish between these constitutive and non-constitutive elements by placing them in different instruments. The constitutive elements establishing the basic institutions and decisionmaking procedures of the regime are entrenched in the treaty text itself, which like a constitution, is difficult to amend. Meanwhile, the regulatory elements are placed in protocols, annexes, or schedules, which are easier to amend, or are adopted as decisions of the parties.

If characterizing international law in constitutional terms merely referred to the constitutive function of many treaties, then such characterizations would not be problematic. But claims about the constitutional status of international law usually serve as shorthand for a stronger set of claims--some putatively descriptive, others more openly normative - that international law is, or should be, a constitutional order in a "thicker" sense. For example, some scholars argue that international law is developing a constitutional character because it

- represents the law of an emerging international community, with shared responsibility and solidarity; ${ }^{36}$

- has a higher status, not dependent on state consent; $;^{37}$

- represents a unified, comprehensive system, rather than a series of discrete regimes; and provides for a process of judicial review. ${ }^{38}$

Others argue that, if international law does not, as a descriptive matter, al ready have these features, then as a normative matter it should develop them. ${ }^{39}$

35. See generally Edward A. Parson, Protecting the Ozone Layer: Science and Strategy (2003).

36. Cottier \& Hertig, supra note 12, at 270-71.

37. Bardo Fassbender, Sovereignty and Constitutionalism in International Law, in SovereIGNTY IN Transition 115, 142 (Neil Walker ed., 2003). On this review, norms of jus cogens represent a higher law with constitutional status.

38. Deborah Z. Cass, the Constitutionalization of the World Trade Organization: Legitimacy, Democracy and Community in the International Trading System 177 (2005).

39. See, e.g., Ernst-Ulrich Petersmann, How to Constitutionalize International Law and Foreign Policy for the Benefit of Civil Society?, $20 \mathrm{MicH}$. J. INT'L L. 1 (1998). 
From a descriptive standpoint, the U.N. Charter is often cited as the preeminent example of an emerging international constitution in this thicker sense. ${ }^{40}$ Like a constitution, the U.N. Charter articulates the fundamental rules of the international system, such as the principles of sovereign equality and self-determination, the prohibition on the use of force, and the obligation to promote and respect human rights. These fundamental rules, although adopted in a treaty requiring state consent, represent more than bargains negotiated by states. Instead, they represent core values of an emerging international political community, which are outside of politics and thus are "no longer dependent on the capriciousness of sometimes well-meaning, sometimes egoistic states." ${ }^{31}$ Also, the rules of the U.N. Charter are intended to provide a stable framework of governance of indefinite duration. Accordingly, they are entrenched, amendment requiring ratification by two-thirds of the member states, including all of the permanent members of the Security Council. ${ }^{42}$ Finally, Article 103 makes the Charter hierarchically superior to other treaties. ${ }^{43}$

Whether even the U.N. Charter establishes a constitution in a thick sense is

40. See, e.g., Pierre-Marie Dupuy, The Constitutional Dimension of the Charter of the United Nations Revisited, 1 Max Planck Y.B.U.N.L. 1, (1993); Fassbender, supra note 1; Thomas M. Franck, Is the U.N. Charter a Constitution?, in Verhandeln für den Frieden (Jochen Abr. Frowein et al. eds., 2003).

41. Fassbender, supra note 37 , at 142.

42. U.N. Charter art. 108.

43. Similar types of claims are made regarding two other leading candidates for constitutional status in international law: the World Trade Organization (WTO) Uruguay Round Agreements and the U.N. Convention on the Law of the Sea (UNCLOS). On the WTO, see, e.g., Cass, supra note 38; Ernst-Ulrich Petersmann, Constitutional Functions and Constitutional Problems of International Economic Law (1991); John H. Jackson, The WTO "Constitution" and Proposed Reforms: Seven “Mantras” Revisited, 4 J. INT'L Econ. L. 67 (2001); see also Dunoff, supra note 6 (stating that writings on WTO constitutionalism focus on different aspects of the WTO regime, including general institutional structure, normative commitments, and mechanisms of judicial review). On UNCLOS, see Shirley V. Scott, The LOS Convention as a Constitutional Regime for the Oceans, in Stability and Change in the Law of the Sea: The Role of the LOS Convention 9 (Alex G. Oude Elferink ed., 2005) (exploring whether the LOS Convention constitutes a constitutional regime). At the end of the UNCLOS negotiations, the president of the negotiating conference, Tommy Koh of Singapore, argued that UNCLOS represented "a constitution for the oceans" because of its comprehensiveness, wide participation, coherence with the wider system of international governance, and promotion of global interests and equity. See David Anderson, "Constitutionalism" and the Law of the Sea (Mar. 14, 2007) (unpublished manuscript), http://www.law.leeds.ac.uk/ leedslaw/webdocs/leedslaw/uploadeddocuments/cfig-anderson.doc (noting that Koh's term has an "element of hyperbole or metaphor"). 
debatable, ${ }^{44}$ and beyond the scope of this article. But international environmental agreements clearly do not establish constitutions. First, they do not typically create systems of governance with significant independence from states. Multilateral environmental agreements addressing climate change, ozone depletion, hazardous chemicals, or endangered species are still very much state-driven. States generally retain the right of exit, meaning they can withdraw from the treaty. ${ }^{45}$ The secretariats established by international environmental agreements are comparatively weak in most cases. It is also unclear whether international environmental agreements even establish international organizations with an independent legal personality. ${ }^{46}$ Although non-state actors play a significant role in the standard-setting and compliance process, this influence is generally extra-constitutional because it takes place through informal processes, outside of the formal arrangements provided for by the regime's foundational instrument.

Second, international environmental agreements do not effectively limit the institutions they establish. Consider, the ICRW. In theory, the ICRW sets limits on how the IWC may operate. According to the ICRW, the IWC should act on a scientific basis, and should have the orderly development, not the abolition, of the whaling industry as its purpose. ${ }^{47}$ Yet these requirements did not prevent the IWC from adopting a moratorium on commercial whaling, which the chairman of the IWC's own scientific committee argued was without scientific basis, ${ }^{48}$ and which is arguably preservationist rather than conservationist in orientation.

44. Even if the U.N. Charter does not create institutions with general law-making or enforcement powers, many of the most fundamental secondary rules of international law are found in other instruments, such as the Vienna Convention of the Law of Treaties and the International Law Commission Articles on State Responsibility. Moreover, the U.N. Charter lacks many of the features of the Western liberal conception of a constitution, including democratic decision-making, a strong separation of powers, and judicial review. See Jose Alvarez, Constitutional Interpretation in International Organizations, in Legitimacy of International Organizations 104, 106-09 (Jean-Marc Coicaud \& Veijo Heiskanen eds., 2001) (describing "unconstitutional" aspects of the U.N Charter); Anderson, supra note 44 (describing a similarly skeptical view of the constitutional status of UNCLOS).

45. See Laurence R. Helfer, Constitutional Analogies in the International Legal System, 37 Loy. L. REv. 193, 228-31 (2003) (discussing the role of exit in international treaty design).

46. This issue has been the subject of dispute in the case of the U.N. Framework Convention on Climate Change. See generally Robin Churchill \& Geir Ulfstein, Autonomous Institutional Arrangements in Multilateral Environmental Agreements: A Little-Noticed Phenomenon in International Law, 94 Aм. J. INT'L L. 623, 648-49 (2000).

47. ICRW, supra note 31 , pmbl. \& art. V, 2(b).

48. In 1993, the Chairman of the IWC's Scientific Committee, Philip Hammond, resigned, saying that he could no longer continue to serve as "spokesman for a Committee which is held in such disregard by the body to which it is responsible." See William Aron et al., The Whaling Issue, 24 Marine PoL'y 179, 180 n.7 (2000). 
As the whaling case illustrates, international environmental agreements are better at constituting than they are at constraining. ${ }^{49}$ They primarily serve to create new political arenas, rather than to take issues outside of politics. The adoption of the 1990 London Amendments to the Montreal Protocol provides another illustration. The Montreal Protocol does not set forth any rule concerning how it may be amended. As a result, the rule governing amendments is found in the Montreal Protocol's parent instrument, the Vienna Convention for the Protection of the Ozone Layer. This convention provides that protocol amendments must be ratified by two-thirds of the protocol parties in order to enter into force.$^{50}$ Despite this constitutional constraint, when the parties to the Montreal Protocol adopted the London Amendments, they decided to avoid this rule by providing that the London Amendments would require ratification by only twenty states in order to enter into force. ${ }^{51}$ In essence, the parties' attitude was, "this is our treaty, and if we want to adopt an amendment, we can do so using whatever rules we like." This atritude may be justified in certain circumstances; the U.S. Constitution was itself adopted by a procedure contrary to the Articles of Confederation. ${ }^{52}$ However, this is hardly an attitude characteristic of those who view the existing legal order as constitutional in character. ${ }^{53}$

Due to these weaknesses, if international environmental agreements qualify as constitutions at all, they are at most constitutions with a little " $c$ " rather than a big "C." They are constitutions in the thin sense that they establish ongoing systems of governance and default rules for how those systems of governance will operate. They are not constitutions in the thicker sense, however, because they fail to establish institutions with significant independence from states, or to take issues outside the zone of politics by imposing effective constraints, either procedural or substantive, on the behavior of international environmental institutions. Nor do these agreements establish a constitutional order for international environmental law as a whole. Instead, they establish a balkanized system, with a

49. See also Klabbers, supra note 28 , at $43-44$.

50. Vienna Convention for the Protection of the Ozone Layer, Mar. 22, 1985, art. 9, 5, T.I.A.S. No. 11,097, 1513 U.N.T.S. 324.

51. Adjustments and Amendments to the Montreal Protocol on Substances that Deplete the Ozone Layer, art. 2, June 29, 1990, 30 I.L.M. 537, 541.

52. Similarly, some argue that the Fourteenth Amendment to the U.S. Constitution was adopted in an extra-constitutional manner. See Bruce Ackerman, We the People: Foundations 21 (1991).

53. Of course, in exceptional circumstances, even domestic constitutions do not necessarily constrain. 
multiplicity of regimes, each with their own constitutions. In essence, they contribute to the phenomenon of fragmentation rather than counteract it. ${ }^{54}$

Is there an international environmental constitution more generally that applies to international environmental law as a whole? Certainly, international environmental law has a number of characteristic features, which serve to distinguish it from classical international law, ${ }^{55}$ such as widespread use of the framework convention and protocol approach, rapid amendment procedures, a distinctive system of treaty bodies, ${ }^{56}$ and non-compliance procedures that are more political than judicial in nature. ${ }^{57}$ But these distinctive features of international environmental law do not amount to a constitution in any meaningful sense of the term. They do not establish unitary requirements with regard to the creation and operation of international environmental law - that is, secondary rules about how international environmental law is developed and enforced. Indeed, some prominent features of international environmental law, such as the use of politically-oriented non-compliance procedures, cut strongly against the concept of constitutionalism. Rather, the distinctive mechanisms of international environmental law represent a toolbox that states can use when addressing a variety of new problems.

A more promising candidate to fill the role of an international environmental constitution is the collection of general principles of international environmental law, including the duty to prevent transboundary harm, the polluter pays principle, the precautionary principle, the principle of common but differentiated responsibility, and the principle of sustainable development, which cut across the various treaty regimes examined earlier. ${ }^{58}$

Do these general principles represent a core value system ${ }^{59}$ for the international community - a set of fundamental, substantive rules that might be analo-

54. I use the word "phenomenon" rather than "problem" deliberately, since it is not clear to me that fragmentation is problematic in the international environmental context. See Martti Koskenniemi \& Päivi Leino, Fragmentation of International Law? Postmodern Anxieties, 15 LeIdeN J. INT'L L. 553 (2002).

55. Daniel Bodansky, Does One Need to be an International Lawyer to be an International Environmental Lawyer?, 100 Proc. AM. Soc'y INT'L L. 303, 303-07 (2006); Daniel Bodansky et al., International Environmental Law: Mapping the Field, in Oxford Handbook of International Environmental Law 1, 5-6 (Daniel Bodansky et al. eds., 2007).

56. See Churchill \& Ulfstein, supra note 47.

57. Martti Koskenniemi, Breach of Treaty or Non-Compliance? Reflections on the Enforcement of the Montreal Protocol, 3 Y.B. Int'L Envtr. L. 123 (1992).

58. On international environmental principles, see generally Nicolas de SAdeleER, Environmental Principles: From Political Slogans to Legal Rules (2002).

59. de Wet, supra note 2, at 53. 
gized to a constitution? Perhaps. But if they do represent an incipient international environmental constitution, it is weak and vague. Although principles such as the precautionary principle and the principle of sustainable development serve to structure international discourse on environmental problems, they have so many different meanings that they hardly exercise real constraint on the behavior of states or international institutions. ${ }^{60}$

Moreover, even to the extent that they do serve a constitutional function by articulating a set of overarching, shared values, this is only one of several constitutional functions. International environmental law still lacks a general system of governance, such as a world environmental organization, which could provide a common framework for the multiplicity of existing international environmental regimes, and it lacks common rules that organize its different regimes. Finally, it lacks other features often associated with constitutionalism, such as judicial review or more generally, a separation of powers.

\section{Does It Matter Whether International Environmental LaW Has a Constitution? A Critique of Analyzing the Constitutional Character of International Law}

Engaging in discussions about the constitutional status of international law assumes that the answer matters because something important is at stake. But is this true? What is the value added of "constitution talk"?

Consider, for example, the descriptive claims regarding the constitutional status of international law. Why can we not consider whether international environmental law is a comprehensive system, or is developing a non-consensual character, or reflects the law of an emerging international community, without regard to the vexing question of whether it has assumed a constitutional character? For instance, having described the UNCLOS as an entrenched, stable system of governance of indefinite duration, intended to address ocean issues comprehensively and with aspirations for universal membership, what does the label "constitution" contribute? $?^{61}$ Similarly, with respect to the normative claims regarding constitutions and constitutionalism, why can we not consider whether judicial review or a

60. See, e.g., Daniel Bodansky, Deconstructing the Precautionary Principle, in Bringing New Law to Ocean Waters 381 (D.D. Caron \& H.N. Scheiber eds., 2004); Christopher D. Stone, Is There a Precautionary Principle?, 31 EnvrL. L. Rep. 10790 (2001) (discussing the different versions and definitions of the "precautionary principle").

61. See Scott, supra note 43. 
diminished role for state consent would be positive without introducing the concept of constitutionalism? What does the concept of constitutionalism add to our analysis of the nature of international law?

The constitutionalist movement in international law has not sufficiently addressed these questions. One possible answer to why the analysis of constitutional status is important is that constitutional discourse serves as a convenient shorthand for a collection of more specific attributes, such as hierarchy and entrenchment. The problem with this response is that the meaning of constitutionalism is so unclear that it seems more likely to confuse than simplify.

Another possible argument for the utility of applying constitutional modes of analysis to international law is that the various features of constitutionalism examined earlier are not disparate phenomenon, but combine into a coherent whole. Thus, we need to study these features in a holistic rather than in a disaggregated manner.

In principle, the holistic nature of constitutionalism could have either an empirical or a normative character, or both. Empirically, if the different elements of constitutionalism are interrelated by standing in some kind of causal relationship with one another, then the presence of one constitutional feature would suggest the presence of others. Examining international law through the empirical lens of constitutionalism would help us to see aspects of the international legal system that might otherwise be overlooked or insufficiently appreciated-for example, the role of proportionality balancing in international dispute resolution, which Alec Stone Sweet argues is a characteristic feature of constitutional adjudication. ${ }^{62}$ One benefit of a domestic analogy such as this is that it allows us to understand international law in new and useful ways.

While these empirical relationships are interesting, the emphasis on constitutional discourse has a primarily normative impetus. In contrast to the descriptive perspective, which presumes an empirical correlation between the different features of constitutionalism, the normative argument is that these different features should go together or combine to take on special normative significance. It follows that if the various features of constitutionalism are normatively related, then the presence of some constitutional features suggests the need for others. For instance, to the extent that an international regime creates an ongoing system of governance that limits state consent, the presence of such a system then creates a need for features like transparency, separation of powers, and judicial review. Or, to the extent that the U.N. Charter serves as a constitution for the international com-

62. Alec Stone Sweet \& Jud Mathews, Proportionality Balancing and Global Constitutionalism, 47 Colum. J. Transnat'l L. 72 (2008). 
munity, it should be able to legitimately make demands on non-member states and non-state actors and develop as a living instrument, including through dynamic-evolutionary interpretation. It should also be open to all states, provide for judicial review, and have direct effect on domestic law.

Whether these arguments are persuasive depends on whether the different features of a constitution are merely additive, or whether, when combined, a new type of governance emerges with properties of its own. If the former, then we would be better off focusing directly on the component elements themselves, and staying away from characterizing them in constitutional terms. In other words, we should consider whether international law has, or should have, elements like judicial review, a doctrine of implied powers, or whatever descriptive or normative features are drawn from the supposedly constitutional character of international law without wrapping these considerations in a constitutional veil, which makes it more difficult to focus on the normative relationships between different features of the international legal system. On the other hand, if the different dimensions of constitutionalism are indeed normatively linked, or provide legitimacy in a way that exceeds the sum of the parts, then it is necessary to study constitutions as a distinctive and holistic phenomenon. ${ }^{63}$

The normative arguments regarding international constitutionalism proceed in different ways depending on whether international law has already developed a constitutional character. That is why the answer to the descriptive question matters regarding whether there is an international environmental constitution. On the one hand, to the extent that international law has already developed into a constitutional order, then this fact has certain normative implications. For example, it might give international law greater legitimacy. It might mean that international law should be seen as superior to national law, or should be interpreted liberally, using a teleological approach befitting a constitution. ${ }^{64}$ On the other hand, to the extent that the international legal system still falls short of a constitutional order, this suggests the need for further constitutionalization. To become more legitimate and effective, and thereby able to compensate for the declining authority of states, the international legal system needs to become more constitutional-for example, by limiting public power through checks and balances, af48.

63. This seems to be the view of Peters, supra note 3, at 581-83, and Klabbers, supra note 28 , at $47-$

64. Tetsuo Sato, Evolving Constitutions of International Organizations (1996); $c f$. Helfer, supra note 45, at 204 (distinguishing WTO dispute settlement from constitutionalism because of its less teleological method). 
fording human rights protections, establishing mechanisms for judicial review, ${ }^{65}$ or creating new constitutional structures appropriate to multilevel governance and shared sovereignty. ${ }^{66}$

The latter belief underlies the recent focus on constitutionalism. Traditionally, international law has relied on state consent for its legitimacy. ${ }^{67}$ But to the extent that nonconsensual norms and decision-making processes will need to play a larger role in the future to respond to collective action problems such as climate change, then international law will need some new basis of legitimacy. At first glance, democracy seems like a potential candidate, but it is difficult to conceive how democracy could operate at the global level in the absence of a global demos. As a result, constitutionalism has become an attractive alternative. ${ }^{68}$ If the various features of constitutionalism, including limited government, separation of powers, judicial review, transparency, and human rights protections represent the touchstone of legitimacy, then the constitutional status of international law matters deeply. In essence, if constitutionalism is a good thing, then giving international law a constitutional character would make international law a good thing as well.

I am sympathetic to this general sentiment, and believe that providing constitutional limits on governance could help legitimize international environmental institutions. Yet, I remain skeptical that we need to think about these constitutional issues in holistic terms. Given the complexity and vagueness of constitutional discourse, as well as the difficulty of achieving the different dimensions of a constitution at once, we might do better by unpacking the concept into its component elements and then considering the proper role of each in the distinctive context of international governance, rather than attempting to ground the legitimacy of international law in its constitutional status tout court.

65. Peters, supra note 3, at 582-83. On judicial review, in particular, see James Crawford, Marbury v. Madison at the International Level, 36 Geo.WAsH. INT'L L. Rev. 505 (2004); Erica de Wet, Judicial Review as an Emerging General Principle of Law and Its Implications for the International Court of Justice, 47 Neth. INT'L L. Rev. 181 (2000).

66. Cottier \& Hertig, supra note 12, at 299-300 (describing a "five storey" constitutional house).

67. Daniel Bodansky, The Legitimacy of International Governance: A Coming Challenge for International Environmental Law?, 93 A M. J. INT'L L. 596, 597 (1999).

68. See Mattias Kumm, The Legitimacy of International Law: A Constitutionalist Framework of Analysis, 15 Eur. J. INT'L L. 907 (2004); Peters, supra note 3, at 580-83, 605-10. Of course, not all would agree about the normative appeal of global constitutionalism. For a contrasting view, see Ernst A. Young, The Trouble with Global Constitutionalism, 38 TEx. INT'L L.J. 527 (2003). 


\section{Conclusion}

States face common global environmental problems, but they do not necessarily have common interests or values. This may account, at least in part, for their weak commitment to constitutionalism and legalization. The refusal by the IWC to lift its moratorium on commercial whaling, the reliance by international environmental regimes on non-judicial compliance procedures, and the adoption of the London Amendments to the Montreal Protocol by a procedure at odds with the regime's requirements are all examples reflecting the fact that in today's world, states still prefer to retain significant flexibility rather than commit to constitutional constraints. They remain far from developing the sense of community that underlies constitutional governance.

Over the long haul, it is unclear whether this state-driven approach will adequately address international environmental problems such as climate change and loss of biodiversity. As I have argued elsewhere, such problems may require the creation of international institutions with greater authority. If this occurs, it could push international environmental law in the direction of greater constitutionalization in order to address concerns about the legitimacy of new and more powerful institutions. But any transformation of this kind lies in the future. For the moment, international environmental law remains a set of commitments by states, rather than a constitutional order. 